\title{
On the role of rock fragments and initial soil water content in the potential subsurface runoff formation
}

\author{
Hana Hlaváčiková*, Viliam Novák, Ladislav Holko \\ Institute of Hydrology, Slovak Academy of Sciences, Račianska 75, 83102 Bratislava, Slovakia. \\ *Corresponding author. E-mail: hlavacikova@uh.savba.sk
}

\begin{abstract}
Stony soils are composed of fractions (rock fragments and fine soil) with different hydrophysical characteristics. Although they are abundant in many catchments, their properties are still not well understood. This article presents basic characteristics (texture, stoniness, saturated hydraulic conductivity, and soil water retention) of stony soils from a mountain catchment located in the highest part of the Carpathian Mountains and summarizes results of water flow modeling through a hypothetical stony soil profile. Numerical simulations indicate the highest vertical outflow from the bottom of the profile in soils without rock fragments under ponding infiltration condition. Simulation of a more realistic case in a mountain catchment, i.e. infiltration of intensive rainfall, shows that when rainfall intensity is lower than the saturated hydraulic conductivity of the stony soil, the highest outflow is predicted in a soil with the highest stoniness and high initial water content of soil matrix. Relatively low available retention capacity in a stony soil profile and consequently higher unsaturated hydraulic conductivity leads to faster movement of the infiltration front during rainfall.
\end{abstract}

Keywords: Stony soils; Infiltration; Stoniness; Initial soil water content; Mathematical modeling.

\section{INTRODUCTION}

Soils containing a significant fraction of rock fragments (stones), generally denoted as stony soils, are located mainly in forested and mountainous areas. According to Poesen and Lavee (1994) there are about $30 \%$ of such soils in Western Europe; in the Mediterranean region stony soils cover around $60 \%$ of the territory. Śály (1978) reports that major portion of the Slovak forest soils (up to 80\%) contains stones and the stone content increases with depth. Even about $47 \%$ of Slovak agricultural soils are referred to as stony soils (Hraško and Bedrna, 1988). Shape, size, degree of weathering, and geological origin of the rock fragments can influence the soil hydrophysical properties, mainly the retention capacity and hydraulic conductivity.

Rock fragments in the soils reduce the effective crosssectional area through which water flows. Furthermore, an increase in stoniness results in higher curvature of soil water paths. Both phenomena consequently lead to a lower hydraulic conductivity of the stony soil (Bouwer and Rice, 1984; Childs and Flint, 1990; Ma et al., 2010; Novák et al., 2011; Ravina and Magier, 1984). On the other hand, the shrinking-swelling phenomenon can create temporal lacunar pores (voids along soil/stone interface), which may cause preferential flow, and thus an increase in the saturated hydraulic conductivity (Sauer and Logsdon, 2002; Shi et al., 2008; Verbist et al., 2009; Zhou et al., 2009). It could be hypothesized that the degree of preferential flow in such soils is proportionally related to the stone content and its spatial distribution (Fiés et al., 2002; Verbist et al., 2009).

The presence of rock fragments poses problems for measuring the bulk soil hydraulic properties and the water content or water potential as well as for the monitoring of the soil water regime because of practical issues such an inserting probes into stony soils (e.g., TDR probes and tensiometers) or installing lysimeters (Cousin et al., 2003; Ma et al., 2010). Moreover, consistent water flow modeling methodology which takes into account rock fragments and their characteristics is still absent (Ma and Shao, 2008).
Rock fragments are relatively large in comparison to fine soil particles, i.e. the particles with diameter below $2 \mathrm{~mm}$. Therefore, it is necessary to evaluate the bulk soil characteristics of a "representative elementary volume" (REV). The REV needed for determination of the bulk hydrophysical soil characteristics of a stony soil depends mostly on the size of the rock fragments. Buchter et al. (1994) recommend that the dry mass of a stony soil sample should be at least 100 times the mass of the largest particle. However, there is not a strict rule on how to evaluate the REV of a stony soil in terms of measuring its hydraulic characteristics.

Since it is technically difficult to perform hydraulic measurements on large samples having different stoniness, Novák et al. (2011) used numerical experiments based on the classical Darcian flow approach to calculate the saturated hydraulic conductivity of stony soil. This was done by embedding stones of different size into a fine soil medium with known hydraulic conductivity and soil water retention, and then calculating the saturated hydraulic conductivity of the bulk sample with stones. They used HYDRUS-2D (Šimůnek and Šejna, 2007) for the calculations. Impermeable stones of a spherical shape (approximated as circles in a 2D cross-sectional area) were equally distributed in the virtual soil sample with a volume of $1 \mathrm{~m}^{3}$. Steady-state water flow was simulated. The rate of water flow through the REV then equals to the bulk saturated hydraulic conductivity $K_{s}^{b}$. Novák et al. (2011) found that hydraulic conductivities obtained from numerical experiments are lower for the same stoniness (relative volume fraction of stones) than those from Ravina and Magier (1984) equation because of hydraulic losses due to bypassing of the stones.

Runoff formation remains one of the central themes of catchment and hillslope hydrology. Although the crucial role of soils in the hydrological response of a catchment has been acknowledged a long time ago (e.g., Hewlett and Hibbert, 1967), functioning of stony soils is still not much studied. In fact, we did not find any study which would be specifically devoted to hydrological behavior of stony soils in catchment conditions. Stony soils are often abundant in headwater areas which are crucial for catchment runoff formation. It is therefore 
important to collect more field data and try to understand the behavior of stony soils during rainfall and their possible influence on the runoff formation.

The objectives of this study were:

- to present characteristics of stony soils from a mountain catchment representing the highest part of the Carpathian Mountains, and

- to quantify and explain the influence of rock fragments and initial soil water content in soil profiles with different stoniness on infiltration and bottom boundary outflow under ponding and rain infiltration when rainfall intensity is lower than the saturated hydraulic conductivity of the stony soil (infiltration capacity).

\section{MATERIALS AND METHODS Study sites}

Characteristics of stony soils were measured in the Jalovecký creek catchment, the Western Tatra Mountains, Slovakia. Natural conditions in the catchment are typical for the highest part of the Carpathians. The bedrock is mostly formed by crystalline rocks and granitoides. Mesozoic rocks dominated by limestone and dolomite occur at some places. Soils are represented by Cambisols, Podzols, and Lithosols. Rendzinas occur on Mesozoic rocks. The rock fragments content of the soils is high, the stoniness is $40-50 \%$ (e.g., Holko et al., 2011). The topsoil of the soils has high hydraulic conductivity. Mean value measured by tension infiltrometer at water potential $\mathrm{h}=-2 \mathrm{~cm}$ (Dóša et al., 2012) reaches $13 \mathrm{~cm} \mathrm{~h}^{-1}$ (range $2-34 \mathrm{~cm} \mathrm{~h}^{-1}$ ).

Four sites were chosen to study the stony soils (Fig.1):

Site 1: Pod Lyscom, forest, 1040 m a.s.l., Cambisol, slope angle $40 \%$.

Site 2: Červenec-meadow, $1500 \mathrm{~m}$ a.s.l., Rendzic Leptosols, slope angle $10 \%$. $30 \%$.

Site 3: Červenec-forest, 1420 m a.s.1., Cambisol, slope angle

Site 4: Bobrovecká Vápenica, grass, $700 \mathrm{~m}$ a.s.l., Fluvisol, at the toe of the mountainous part of the catchment.

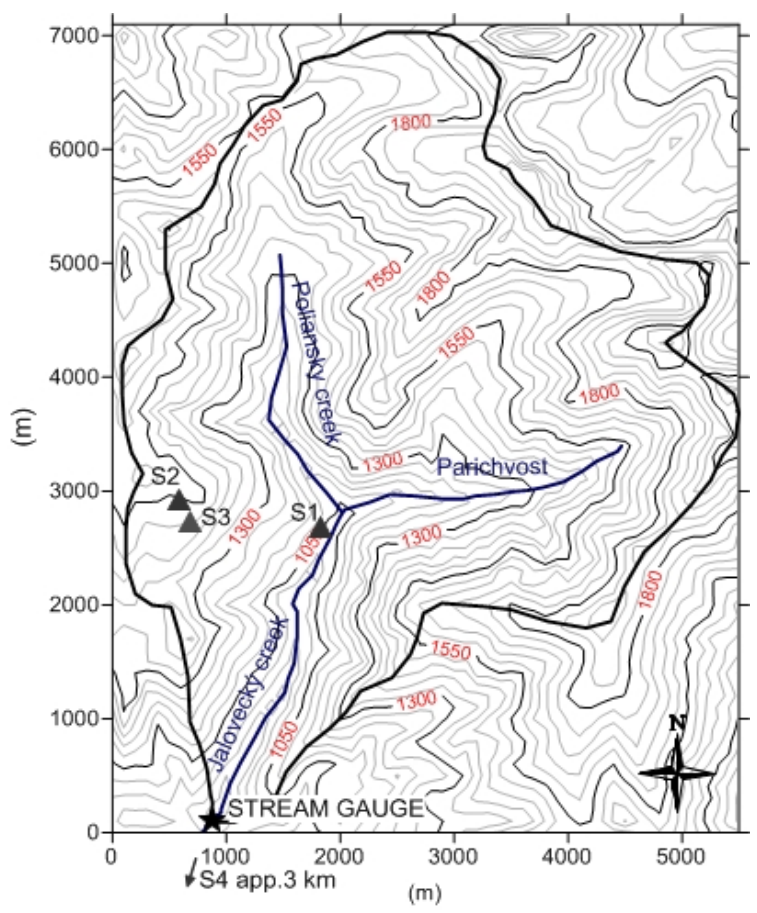

Fig. 1. High mountainous Jalovecký creek catchment.
Test pits of $1 \mathrm{~m}^{2}$ cross section were dug to $70-95 \mathrm{~cm}$ depth to the soil substrate at each site in summer 2012. Additional pit was dug at Site 3 in 2013 to depth of $95 \mathrm{~cm}$. Disturbed soil samples of volume $2000-3000 \mathrm{~cm}^{3}$ were collected for each characteristic soil layer. The samples were used to evaluate the fine soil fraction and volume of gravel part of stoniness. Rock fragments (about 13-22 samples from each experimental site) were collected for maximum water retention capacity measurements. Limited undisturbed soil samples of volume $100 \mathrm{~cm}^{3}$ were taken for each characteristic soil layer from Sites 1, 2 and 3 for fine soil saturated hydraulic conductivity and water retention measurements.

\section{Characteristics of stony soils}

Soil particle density distribution was determined in the certified laboratory by standard aerometric method based on sedimentation known as the Casagrande method (Lovelland and Whalley, 2001) for particles $<2 \mathrm{~mm}$ or by sieving (for particles $>2 \mathrm{~mm}$ ). The volume of stones and boulders was measured in the field. Undisturbed and disturbed soil samples (volume 100 $\mathrm{cm}^{3}$ ) were used to determine saturated hydraulic conductivity of the fine soil in the laboratory by the variable hydraulic head method. Limited field measurements of saturated hydraulic conductivity were performed by means of single ring infiltrometer as well.

Maximum retention capacity of the rock fragments (size $2-10 \mathrm{~cm}$ ) was determined by the gravimetric method. The samples were dried at $105^{\circ} \mathrm{C}$, weighted and gradually saturated for up to 7 days until their weight stabilized. Retention curves of the undisturbed fine soil samples were measured in the sand tank (negative pressure up to $-30 \mathrm{~cm}$ ) and pressure chamber (Soil Moisture Equipment, Santa Barbara). Measured soil water retention curves were fitted by analytical van Genuchten model (1980).

\section{Influence of rock fragments and initial soil water content on outflow from the soil}

Influence of rock fragments and initial soil water content on infiltration and bottom boundary outflow was studied by means of mathematical modeling using the stony soil and rainfall characteristics measured at the Červenec-meadow site. HYDRUS-1D model (Šimůnek et al., 2008) was used to simulate the water flow through the soil profile.

\section{Hydraulic characteristics of the stony soil}

Saturated hydraulic conductivities and retention curves are needed for quantitative description of the soil water movement in stony soils. We used hydrophysical properties of the fine soil fraction to derive the bulk stony soil characteristics of hypothetical stony soil profiles with different stoniness.

Only a few methods to calculate saturated hydraulic conductivity of a stony soil can be found in the literature (e.g., Bouwer and Rice, 1984; Brakensiek et al., 1986; Peck and Watson, 1979; Ravina and Magier, 1984). In this study we used the equation by Ravina and Magier (1984) adjusted by Novák et al. (2011):

$K_{s}^{b}=\left(1-a R_{v}\right) K_{s}^{f}$

where $K_{s}^{b}$ is the bulk (signed " $b$ ") saturated hydraulic conductivity $\left(\mathrm{cm} \mathrm{h}^{-1}\right), K_{s}^{f}$ is the saturated hydraulic conductivity 
of a fine soil fraction (signed " $f$ ") $\left(\mathrm{cm} \mathrm{h}^{-1}\right), a$ is parameter that incorporates the hydraulic resistance of the rock fragments to water flow and depends on the shape and dimensions of rock fragments (-), $R_{v}$ stands for a relative volume fraction of stones $\left(\mathrm{cm}^{3} \mathrm{~cm}^{-3}\right)$ (stoniness). Parameter $a$ was set to 1.1 . Such a value was estimated by Novák et al. (2011) for sandy loam and spherical rock fragments of a $10 \mathrm{~cm}$ in diameter.

Water retention curve of a stony soil (bulk water retention curve) was represented by the retention curve of the fine soil fraction measured by the above mentioned standard procedures in the sand tank and the pressure chamber. The fine soil sampled at the depth of $53.5-57 \mathrm{~cm}$ at the Červenec-meadow site was used as typical for the whole soil profile to demonstrate the application of the proposed methodology.

Relationship between water content of the stony soil and water content of the fine soil fraction is estimated by Bouwer and Rice's equation (1984):

$\theta^{b}=\left(1-R_{v}\right) \theta^{f}$

where $\theta^{b}$ is the bulk volumetric water content of the stony soil $\left(\mathrm{cm}^{3} \mathrm{~cm}^{-3}\right), \theta^{f}$ is the volumetric water content of the fine soil fraction alone $\left(\mathrm{cm}^{3} \mathrm{~cm}^{-3}\right)$. Eq. (2) assumes that rock fragments have zero retention capacity. Since the retention capacities of rock fragments from all study sites were quite low (as will be seen from measurement results), they were neglected in the numerical modeling. Coppola et al. (2013) used the similar methodology to derive characteristics of stony soil for modeling.

Retention curves and hydraulic conductivities are expressed by the modified van Genuchten-Mualem model (Schaap and van Genuchten, 2005) with fixed minimum non-zero capillary height $h_{s}=-2 \mathrm{~cm}$, recommended for soils with $\mathrm{n}<1.3$ (Vogel et al., 2001; Schaap and van Genuchten, 2005) to avoid problems with numerical convergence.

\section{Numerical modeling}

HYDRUS-1D model (Šimůnek et al., 2008) was used to simulate infiltration into hypothetical homogeneous stony soil profiles with different stoniness and initial soil water contents, using the nonlinear Richards' equation.

It was assumed that:

- close connection exists between rock fragments and fine soil fraction. Thus, it is assumed that no macropores exist on the contact of the fine soil-rock fragments and the water flows through soil matrix only,

- preferential flow is negligible, and

- the rock fragments have negligible (zero) retention capacity. This is consistent with measurements in the Jalovecký creek catchment, where the maximum volumetric water content of rock fragments was very low.

Two different boundary conditions on the soil surface were used:

1. Dirichlet boundary condition with $2 \mathrm{~cm}$ water layer to model ponding infiltration.

2. Extreme precipitation event measured on May 17, 2006 at meteorological station Červenec (1500 m a.s.1.) multiplied by the factor of 4 was used to simulate the rainfall infiltration. This hypothetical event was used to demonstrate the ability of the soil to transform an extreme rainfall into soil water. Total daily precipitation of this extreme event was $166 \mathrm{~mm}$ which is com- parable with the most extreme daily precipitation observed in the nearby High Tatra Mountains in the last fifty years (Bičárová and Holko, 2013).

Homogeneous soil profiles with depth $95 \mathrm{~cm}$ and different stoniness $\left(R_{v}=0 ; 0.1 ; 0.2 ; 0.3 ; 0.4 ; 0.5 \mathrm{~cm}^{3} \mathrm{~cm}^{-3}\right)$ were used in simulations. Evapotranspiration from the soil surface was neglected because of short duration of the studied processes. Initial conditions were given by uniformly distributed soil water potentials: $h=-300,-1000,-5000,-10000$ and $-15000 \mathrm{~cm}$ thus they represent different initial soil water contents. Bottom boundary condition was set as free drainage by which it is assumed that all water which percolates to the bottom of the soil profile contributes to the subsurface flow formation.

Uniform stoniness and uniformly distributed stones were assumed in the soil profile. The latter cannot be simulated by the $1 \mathrm{D}$ model but it was handled by using parameter $a$ in Eq. 1 from Novák et al. (2011) derived for uniformly distributed stones.

The HYDRUS model was used to simulate cumulative infiltration, cumulative outflow and infiltration front movement. The 1D model with bulk characteristics of stony soil derived from Eq. (1) and Eq. (2) (as effective medium values) was used. The simulation performance in this case is faster and the simulated results (i.e. cumulative infiltration, cumulative outflow and movement of the infiltration front) are the same as if they were modeled by the $2 \mathrm{D}$ model with heterogeneous structure (i.e. rock fragments embedded in fine soil, uniformly distributed as assumed by Novák et al. (2011)). The stony soil in the $2 \mathrm{D}$ model is characterized by the embedded rock fragments with zero retention and zero hydraulic conductivity. The fine soil parameters are given separately (retention and saturated hydraulic conductivity). In contrast to $1 \mathrm{D}$ approach, a $2 \mathrm{D}$ model is able to show the variation of water content and velocities around embedded rock fragments during simulation. These results cannot be obviously modeled using the 1D approach. Nevertheless, such a detailed distribution of the velocities or water content in the soil profile was not necessary in this study; we focused only on the flow across the boundaries (infiltration and outflow).

\section{RESULTS \\ Characteristics of the stony soils}

Genetic horizons, soil texture, size of the rock fragments, and stoniness for different layers at the four study sites are given in Table 1 and Fig. 2. Fig. 3 shows the stoniness at Site 3, measured in summer 2013.

Although the stoniness at the particular sites varies from several per cents to almost $65 \%$, at most sites it is high. High heterogeneity of stoniness between sites can be seen in Fig. 2 and Fig. 3. The highest stoniness was observed in the Cambisol which represents deluvial sediments formed on gneiss (crystalline rocks) in the Jalovecká dolina valley (Site 1) and in the Cambisol that occurs in the transition zone between the crystalline rocks (gneiss) and Mesozoic nappes at Site 3 (especially measured in 2013). The smallest stoniness was observed in Rendzina formed on the Mesozoic rocks (Site 2). Stoniness in the Fluvisol which occurs at the toe of the mountain part of the catchment (Site 4) is highly variable even within the soil profile. The high variability is the result of particular pedogenetic processes. Even the thin layer without rock fragments in the depth of $45-50 \mathrm{~cm}$ was found at the site. Rock fragments at Site 4 were rounded off with different size, shape, and origin (gneiss, granitoides, limestones). 
Table 1. Genetic horizons, soil texture and particle size distribution of stony soils at the study sites. Clay $(<0.002 \mathrm{~mm})$, silt $(0.002-0.05 \mathrm{~mm})$ and sand $(0.05-2 \mathrm{~mm})$ fraction is expressed in mass content, rock fragments fractions (higher than $2 \mathrm{~mm})$ are expressed in volumetric content.

\begin{tabular}{|c|c|c|c|c|c|c|c|c|c|c|c|}
\hline \multirow[b]{2}{*}{$\begin{array}{l}\text { Genetic } \\
\text { horizon }\end{array}$} & \multirow[b]{2}{*}{$\begin{array}{c}\text { Horizon } \\
\text { depth }\end{array}$} & \multirow[b]{2}{*}{$\begin{array}{l}\text { Soil texture } \\
\text { (USDA) }\end{array}$} & \multicolumn{4}{|c|}{ fine soil fraction } & \multirow{2}{*}{$\begin{array}{c}\text { gravel } \\
2-10 \\
\mathrm{~mm} \\
(\%)\end{array}$} & \multirow[b]{2}{*}{$\begin{array}{c}\text { gravel } \\
10-50 \\
\mathrm{~mm} \\
(\%)\end{array}$} & \multirow[b]{2}{*}{$\begin{array}{c}\text { stones } \\
50-250 \\
\mathrm{~mm} \\
(\%)\end{array}$} & \multirow[b]{2}{*}{$\begin{array}{c}\text { boulders } \\
>250 \\
\mathrm{~mm} \\
(\%)\end{array}$} & \multirow[b]{2}{*}{$\begin{array}{c}\text { Total } \\
R_{v} \\
(\%)\end{array}$} \\
\hline & & & $\begin{array}{c}\text { clay } \\
<0.002 \\
\mathrm{~mm} \\
(\%)\end{array}$ & $\begin{array}{c}\text { silt } \\
0.002-0.05 \\
\mathrm{~mm} \\
(\%)\end{array}$ & $\begin{array}{c}\text { sand } \\
0.05-2 \\
\mathrm{~mm} \\
(\%)\end{array}$ & $\begin{array}{c}\text { particle } \\
\text { density } \rho_{\mathrm{s}} \\
\left(\mathrm{g} \mathrm{cm}^{-3}\right)\end{array}$ & & & & & \\
\hline Site 1 & Dystrict car & isol & & & & & & & & & \\
\hline $\mathrm{O}_{\mathrm{o}}$ & $0-5 \mathrm{~cm}$ & - & - & - & - & - & 0.0 & 0.0 & 0.0 & 0.0 & 0.0 \\
\hline $\mathrm{A}_{\mathrm{o}}$ & $5-15 \mathrm{~cm}$ & - & - & - & - & - & 1.7 & 3.8 & 4.9 & 34.1 & 44.5 \\
\hline $\mathrm{A} / \mathrm{B}$ & $15-35 \mathrm{~cm}$ & sandy loam & 1.68 & 35.43 & 62.89 & 2.39 & 5.2 & 3.9 & 10.0 & 22.0 & 41.1 \\
\hline $\mathrm{B}_{\mathrm{v}}$ & $35-70 \mathrm{~cm}$ & sandy loam & 1.5 & 34.61 & 63.89 & 2.51 & 6.6 & 4.2 & 12.2 & 8.5 & 31.6 \\
\hline Site 2 & Rendzic lep & sols & & & & & & & & & \\
\hline $\mathrm{A}_{\mathrm{m}}$ & $0-20 \mathrm{~cm}$ & - & - & - & - & - & 1.4 & 0.0 & 0.0 & 0.0 & 1.4 \\
\hline $\mathrm{A} / \mathrm{C}$ & $20-35 \mathrm{~cm}$ & sandy loam & 6.79 & 45.22 & 47.99 & 2.68 & 7.0 & 2.2 & 0.0 & 0.0 & 9.1 \\
\hline $\mathrm{A} / \mathrm{C}$ & $35-95 \mathrm{~cm}$ & sandy loam & 5.9 & 35.8 & 58.3 & 2.69 & 7.9 & 5.3 & 0.0 & 0.0 & 13.2 \\
\hline Site 3 & Dystrict car & isol & & & & & & & & & \\
\hline $\mathrm{A}_{\mathrm{o}}$ & $0-10 \mathrm{~cm}$ & - & - & - & - & - & 0.0 & 0.0 & 0.0 & 0.0 & 0.0 \\
\hline $\mathrm{B}_{\mathrm{v}}$ & $10-40 \mathrm{~cm}$ & sandy loam & 1.39 & 30.66 & 67.95 & 2.55 & 11.7 & 5.8 & 0.9 & 0.0 & 18.4 \\
\hline $\mathrm{B}_{\mathrm{v}}$ & $40-90 \mathrm{~cm}$ & sandy loam & 1.38 & 30.68 & 67.94 & 2.63 & 17.1 & 6.9 & 7.9 & 3.0 & 34.9 \\
\hline Site 4 & Fluvisol & & & & & & & & & & \\
\hline $\mathrm{A}_{\mathrm{o}}$ & $0-15 \mathrm{~cm}$ & - & - & - & - & - & 0.0 & 0.0 & 0.0 & 0.0 & 0.0 \\
\hline $\mathrm{A}$ & $15-25 \mathrm{~cm}$ & - & - & - & - & - & 9.8 & 4.1 & 2.5 & 0.0 & 16.3 \\
\hline $\mathrm{A}$ & $25-35 \mathrm{~cm}$ & - & - & - & - & - & 9.7 & 5.5 & 11.3 & 0.0 & 26.5 \\
\hline $\mathrm{A}$ & $35-40 \mathrm{~cm}$ & loamy sand & 1.15 & 27.15 & 71.7 & 2.63 & 15.0 & 19.3 & 14.2 & 0.0 & 48.5 \\
\hline $\mathrm{A}$ & $40-45 \mathrm{~cm}$ & sand & 0.63 & 12.93 & 86.44 & 2.69 & 9.5 & 7.6 & 14.2 & 0.0 & 31.4 \\
\hline $\mathrm{RA}^{*}$ & $45-50 \mathrm{~cm}$ & - & - & - & - & - & 0.0 & 0.0 & 0.0 & 0.0 & 0.0 \\
\hline $\mathrm{RA}^{*}$ & $50-70 \mathrm{~cm}$ & - & - & - & - & - & 3.8 & 4.5 & 2.2 & 0.0 & 10.4 \\
\hline $\mathrm{RA}^{*}$ & $70-95 \mathrm{~cm}$ & - & - & - & - & - & - & - & 40.0 & - & 40.0 \\
\hline
\end{tabular}

${ }^{*}$ at Site 4 from depth $45 \mathrm{~cm}$ below burried rendzic occurs

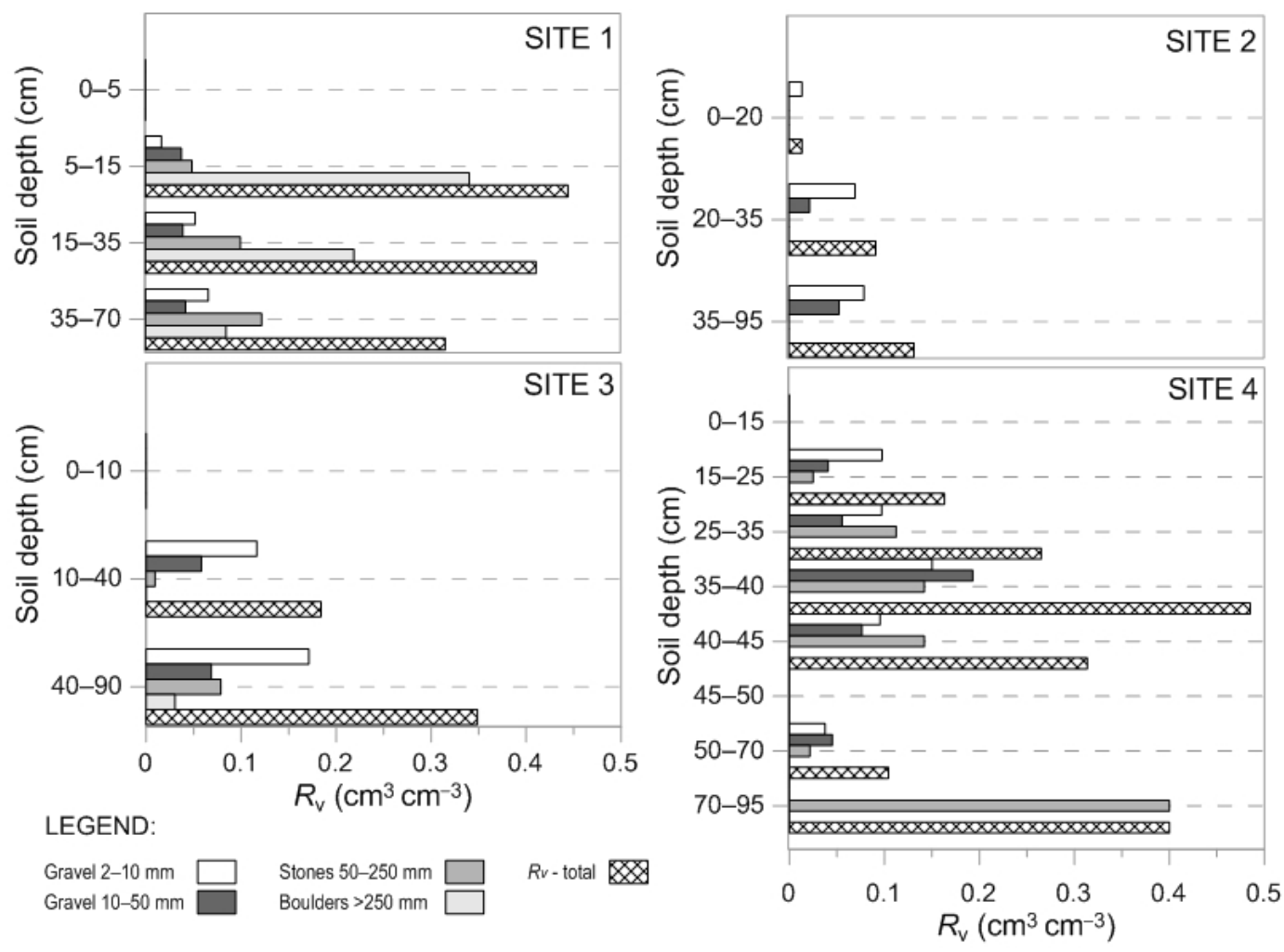

Fig. 2. Stoniness distribution $R_{\mathrm{v}}\left(\mathrm{cm}^{3} \mathrm{~cm}^{-3}\right)$ at different depths of four sites studied in year 2012 . 


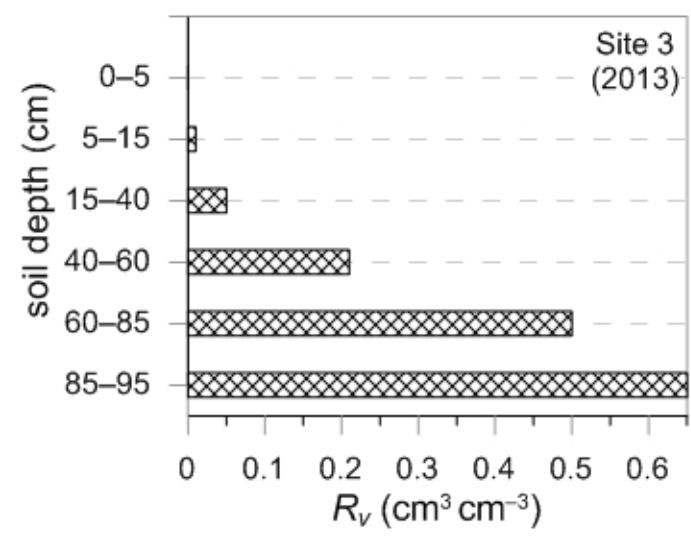

Fig. 3. Stoniness distribution $R_{\mathrm{v}}\left(\mathrm{cm}^{3} \mathrm{~cm}^{-3}\right)$ at different depths at Site 3 studied in year 2013 .

Because of difficulties with measurement of saturated hydraulic conductivity of fine soil fraction in the field, repeated laboratory measurements of saturated hydraulic conductivity for two disturbed samples collected from the same layer were performed. The saturated hydraulic conductivity of fine soil is high at all sites except for Site 2 (Table 2).

Table 2. Saturated hydraulic conductivity $K_{s}$ measured in laboratory (for $\mathrm{T}=20^{\circ} \mathrm{C}$ ), bulk density $\rho_{d}$ and porosity.

\begin{tabular}{|c|c|c|c|c|}
\hline Site & $\begin{array}{l}\text { Soil depth } \\
\text { (cm) }\end{array}$ & $\begin{array}{c}K_{s} \\
\left(\mathrm{~cm} \mathrm{~h}^{-1}\right)\end{array}$ & $\begin{array}{c}\rho_{d} \\
\left(\mathrm{~g} \mathrm{~cm}^{-3}\right)\end{array}$ & $\begin{array}{c}\text { Porosity } \\
\left(\mathrm{cm}^{3} \mathrm{~cm}^{-3}\right)\end{array}$ \\
\hline \multicolumn{5}{|c|}{ undisturbed samples } \\
\hline 1 & $3-6.5$ & 285.8 & 0.13 & - \\
\hline 1 & $6.5-10$ & 447.6 & 0.14 & - \\
\hline 2 & $15-18.5$ & 1.2 & 1.08 & 0.60 \\
\hline 2 & $50-53.5$ & 4.5 & 1.18 & 0.56 \\
\hline 2 & $53.5-57$ & 19.8 & 1.25 & 0.53 \\
\hline \multicolumn{5}{|c|}{ disturbed samples } \\
\hline 1 & $0-8$ & 41.4 & 0.51 & - \\
\hline 1 & $0-8$ & 123.0 & 0.48 & - \\
\hline 1 & $20-30$ & 101.0 & 0.58 & 0.76 \\
\hline 1 & $20-30$ & 37.6 & 0.62 & 0.74 \\
\hline 1 & $30-70$ & 55.1 & 0.71 & 0.72 \\
\hline 1 & $30-70$ & 16.8 & 0.70 & 0.72 \\
\hline 2 & $0-23$ & 2.8 & 1.06 & 0.60 \\
\hline 2 & $0-23$ & 2.2 & 1.05 & 0.61 \\
\hline 2 & $20-35$ & 1.3 & 1.23 & 0.54 \\
\hline 2 & $20-35$ & 2.0 & 1.23 & 0.54 \\
\hline 2 & $35-40$ & 6.3 & 1.24 & 0.54 \\
\hline 2 & $35-40$ & 13.0 & 1.21 & 0.55 \\
\hline 3 & $30-40$ & 23.6 & 0.73 & 0.71 \\
\hline 3 & $30-40$ & 25.5 & 0.72 & 0.72 \\
\hline 3 & $50-60$ & 21.6 & 0.81 & 0.69 \\
\hline 3 & $50-60$ & 12.9 & 0.81 & 0.69 \\
\hline 4 & $15-25$ & 21.4 & 0.99 & 0.62 \\
\hline 4 & $25-35$ & 15.2 & 1.08 & 0.59 \\
\hline 4 & $35-40$ & 14.5 & 1.17 & 0.55 \\
\hline 4 & $40-45$ & 18.9 & - & - \\
\hline 4 & $50-70$ & 5.4 & 1.13 & 0.57 \\
\hline
\end{tabular}

Results of field measurement of saturated hydraulic conductivity by the single ring infiltrometer are given in Table 3. The upper organic horizons have high hydraulic conductivities (Table 2 - undisturbed samples, Table 3 - soil surface) due to properties of the topsoil (high porosity at Sites 1 and 3 in forest) and the presence of preferential pathways in root zone of the grass canopy (Sites 2,4). Saturated hydraulic conductivity measured by single ring infiltrometer in depth 20 and $50 \mathrm{~cm}$ corresponds to the bulk saturated hydraulic conductivity (fine soil and rock fragments).

Table 3. Field saturated hydraulic conductivity determined from the single ring infiltrometer experiment.

\begin{tabular}{ccc}
\hline Site & $\begin{array}{c}\text { Soil depth } \\
(\mathrm{cm})\end{array}$ & $\begin{array}{c}K_{\mathrm{s}, \text { field }} \\
\left(\mathrm{cm} \mathrm{h}^{-1}\right)\end{array}$ \\
\hline 1 & 50 & 57.9 \\
1 & 50 & 20.0 \\
2 & soil surface & 154.2 \\
3 & 20 & 18.0 \\
3 & 50 & 12.0 \\
4 & soil surface & 395.8 \\
\hline
\end{tabular}

Maximum water retention capacity of the rock fragments is low. Median of the volumetric water content values varies between 2 and $6 \%$ (Fig. 4). Our results indicate that maximum retention capacity does not depend on the bedrock geology.

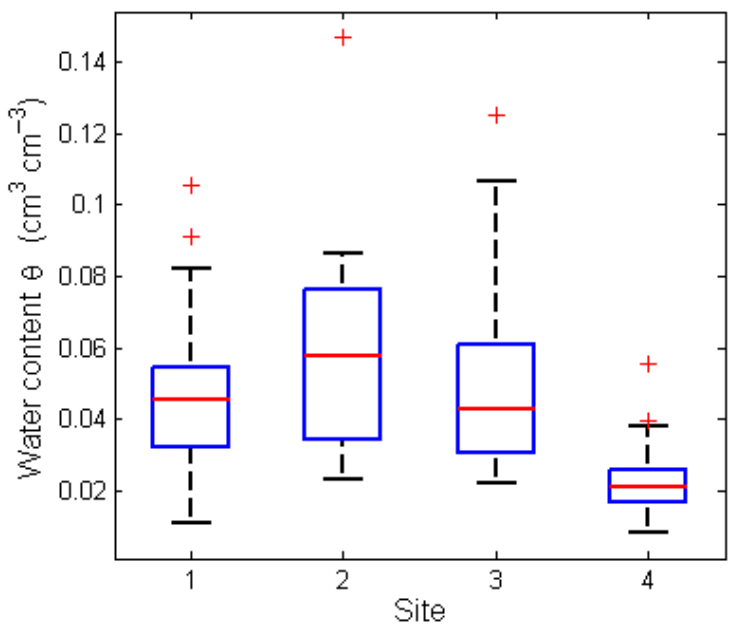

Fig. 4. Saturated volumetric water content of the rock fragments. Value range: $\min , 25^{\text {th }}$ percentile, median, $75^{\text {th }}$ percentile, max, + extreme values (above the $99.3 \%$ percentile).

Van Genuchten parameters of typical water retention curve of fine soil from Site 2 are given in Table $4\left(R_{\mathrm{v}}=0 \mathrm{~cm}^{3} \mathrm{~cm}^{-3}\right)$.

Influence of rock fragments and initial soil water content on outflow from the soil obtained by the numerical modeling

Parameters of the bulk retention curves for different stoniness $\left(\theta_{\mathrm{r}}\right.$ and $\theta_{\mathrm{s}}$ values derived from Eq. 2) and corresponding bulk saturated hydraulic conductivities (derived from Eq. 1) used as input parameters in numerical modeling are presented in Table 4 and Fig. 5. 
Table 4. Soil water retention curve parameters and saturated hydraulic conductivity derived for stony soil with different stoniness $R_{v}$, using the fine soil retention curve $\left(R_{v}=0 \mathrm{~cm}^{3} \mathrm{~cm}^{-3}\right.$, Site 2: Červenec-meadow, depth 53.5-57 cm); $\theta_{r}, \theta_{s}$ and $K_{s}$ are residual and saturated soil water contents and saturated hydraulic conductivity, respectively.

\begin{tabular}{ccccccc}
\hline$R_{\mathrm{v}}\left(\mathrm{cm}^{3} \mathrm{~cm}^{-3}\right)$ & 0 & 0.1 & 0.2 & 0.3 & 0.4 & 0.5 \\
\hline$\theta_{r}^{b}\left(\mathrm{~cm}^{3} \mathrm{~cm}^{-3}\right)$ & 0.05 & 0.045 & 0.04 & 0.035 & 0.03 & 0.025 \\
$\theta_{s}^{b}\left(\mathrm{~cm}^{3} \mathrm{~cm}^{-3}\right)$ & 0.495 & 0.446 & 0.396 & 0.347 & 0.297 & 0.248 \\
$\alpha\left(\mathrm{cm}^{-1}\right)$ & 0.018 & 0.018 & 0.018 & 0.018 & 0.018 & 0.018 \\
$n(-)$ & 1.094 & 1.094 & 1.094 & 1.094 & 1.094 & 1.094 \\
$K_{s}^{b}\left(\mathrm{~cm} \mathrm{~h}^{-1}\right)$ & $19.79 *$ & 17.61 & 15.44 & 13.26 & 11.08 & 8.91 \\
\hline
\end{tabular}

*measured value, upper index " $b "$ stands for bulk characteristic
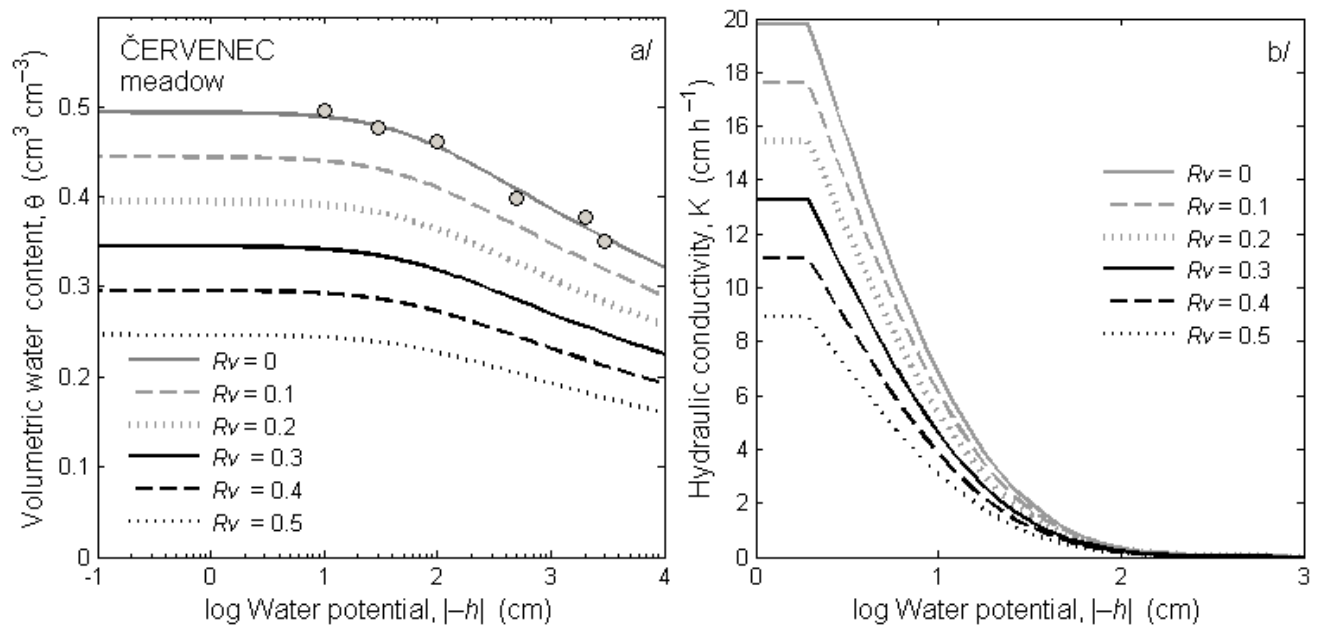

Fig. 5. Soil water retention curves (a) derived for stony soil with different stoniness $R_{v}$ estimated from fine soil fraction retention curve $\left(R_{v}=0 \mathrm{~cm}^{3} \mathrm{~cm}^{-3}\right.$, Červenec-meadow, depth $\left.53.5-57 \mathrm{~cm}\right)$ and corresponding hydraulic conductivities (b). Circles represent measured water retention data of the fine soil fraction.

\section{Infiltration and outflow under ponding condition}

Cumulative infiltration and outflow from the bottom of the soil profile with the initial soil water content corresponding to the soil water potential $h=-300 \mathrm{~cm}$ is shown in Fig. 6 . The wetting front in the soil without rock fragments $\left(R_{v}=\right.$ $0 \mathrm{~cm}^{3} \mathrm{~cm}^{3}$ ) reached the bottom boundary after $15 \mathrm{~min}$. Movement of the water front in soil profile with $R_{v}=0.5 \mathrm{~cm}^{3}$ $\mathrm{cm}^{-3}$ was slower (approximately $18 \mathrm{~min}$ ). Although the difference is not significant, the cumulative infiltration to the soil with $R_{v}=0 \mathrm{~cm}^{3} \mathrm{~cm}^{-3}$ is two times higher than in the case of $R_{v}=0.5 \mathrm{~cm}^{3} \mathrm{~cm}^{-3}$. Such behavior is caused by the decreasing effective cross-section of fine soil with increasing stoniness which leads to decreased saturated hydraulic conductivity and retention capacity of a stony soil. Initially, relatively high infiltration rates are decreasing until they reach the rate corresponding to the saturated hydraulic conductivity. Consequently, infiltration rate equals to the bottom boundary outflow rate and is controlled only by the saturated hydraulic conductivity of the soil profile. The infiltration front moves slower in the stony soil compared to the non-stony soil. Maximum cumulative outflow occurs in the soil without stones as a result of the highest bulk porosity and the highest saturated hydraulic conductivity. Cumulative outflows are indirectly proportional to the stoniness.

\section{Infiltration and outflow during precipitation}

We assume that the above described infiltration under ponding conditions does not frequently occur in steep mountain catchments. Infiltration of an extreme rainfall (Fig. 7) is presumably closer to reality. The results of two scenarios with different initial soil water content are shown in Fig. 8. The soil water potential $h=-15000 \mathrm{~cm}$ (wilting point) occurs in the field rarely. It was used to demonstrate an extreme situation.

The infiltration rate corresponds approximately to rainfall rate (initial losses were neglected), because maximum rainfall rate of $5.4 \mathrm{~cm} \mathrm{~h}^{-1}$ is smaller than the lowest estimated saturated hydraulic conductivity of the stony soil $K_{s}^{b}=8.9 \mathrm{~cm} \mathrm{~h}^{-1}$ for $R_{v}=$ $0.5 \mathrm{~cm}^{3} \mathrm{~cm}^{-3}$ (Table 4).

The bottom boundary outflow of the soil profile starts sooner in the soil with higher stoniness $\left(R_{v}=0.5 \mathrm{~cm}^{3} \mathrm{~cm}^{-3}\right)$ than in the soil without rock fragments $\left(R_{v}=0 \mathrm{~cm}^{3} \mathrm{~cm}^{-3}\right)$ (Figs. 8 and 9). This is in contrary with the ponding situation (Fig. 6). Cumulative outflows are proportional to the stoniness (Fig. 9). There are several reasons of such behavior. Infiltration in this case is performed under unsaturated conditions (in comparison to saturated conditions that develop under ponding). Since rock fragments present in the soil limit the volume of fine soil matrix, less infiltrating water is needed to increase the water content in the matrix of the stony soil and related unsaturated hydraulic conductivity. Consequently, a faster movement of the wetting front in the stony soil is observed. 

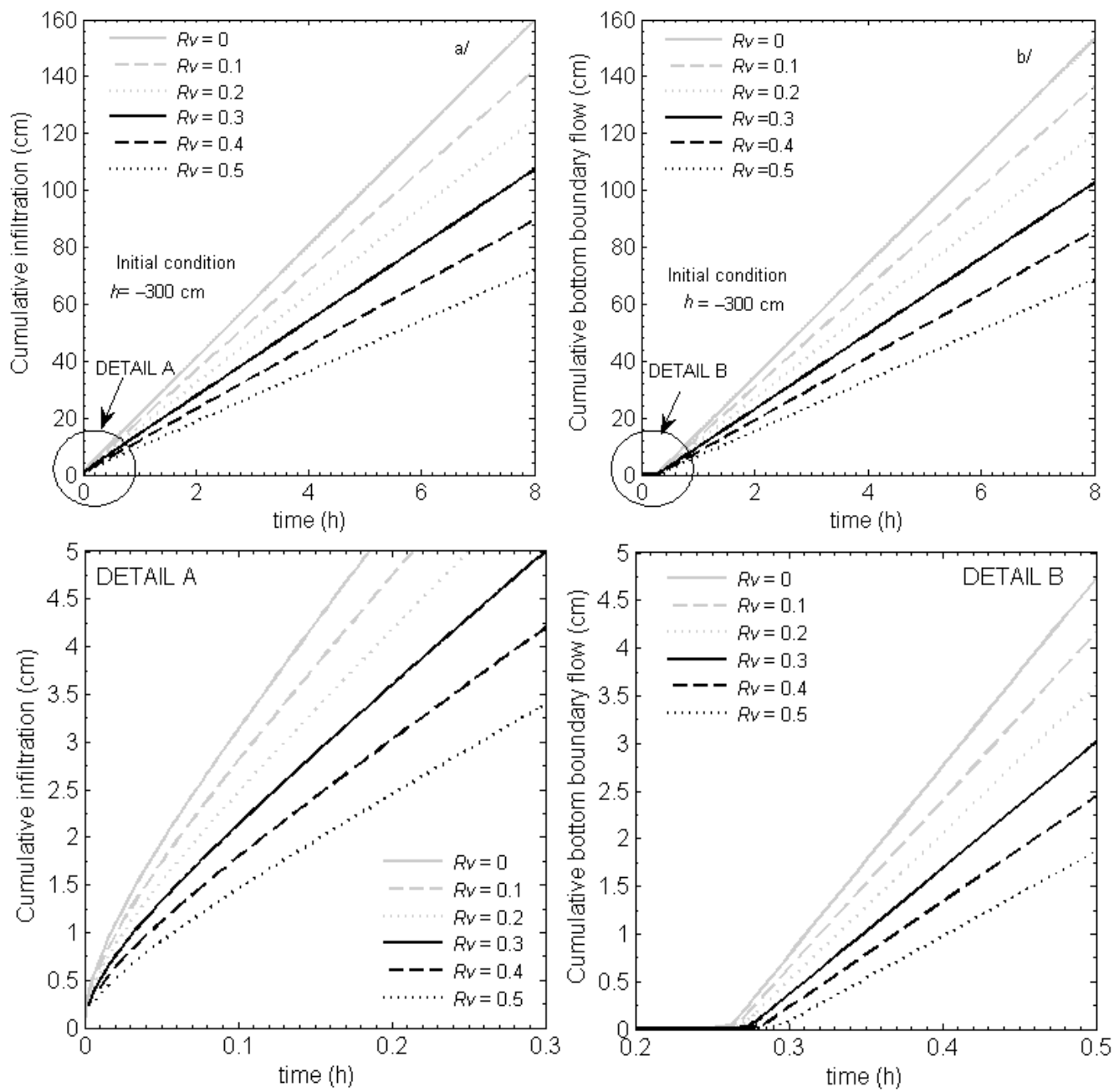

Fig. 6. Cumulative infiltration (a) and cumulative bottom boundary flow (b) from ponded soil surface for soils with different stoniness $R_{v}$ and for initial soil water content corresponding to water potential $h=-300 \mathrm{~cm}$. Cumulative infiltration (detail A) and bottom boundary flow (detail B) for (a) and (b) in case of ponding.

The beginning of the bottom boundary outflow depends on initial SWC too; at $h=-300 \mathrm{~cm}$, the bottom boundary outflow started relatively quickly (from 1.68 hours for $R_{v}=0.5 \mathrm{~cm}^{3} \mathrm{~cm}^{-3}$ to 2.15 hours for $R_{v}=0 \mathrm{~cm}^{3} \mathrm{~cm}^{-3}$ from the beginning of the rain event) (Fig. 8a). This phenomenon is in accordance with the effect of "catchment saturation" which strongly influences the runoff. Maximum outflow rates were the same for all stoniness values $\left(5.4 \mathrm{~cm} \mathrm{~h}^{-1}\right)$, because infiltration front reached the bottom of the soil profile during the simulated rainfall event (Fig. 8).

The beginning of the bottom boundary outflow for the initial SWC corresponding to soil water potential $h=-15000 \mathrm{~cm}$ and $R_{v}=0.5 \mathrm{~cm}^{3} \mathrm{~cm}^{-3}$ started 3.41 hours after the rain beginning and 5 hours after the rain beginning for stoniness $R_{v}=0 \mathrm{~cm}^{3} \mathrm{~cm}^{-3}$. Beginning of the outflow rate was delayed for $R_{v}=0 \mathrm{~cm}^{3} \mathrm{~cm}^{-3}$ case due to high retention capacity of relatively dry soil $(h=-15000 \mathrm{~cm})$ (Fig. 8b).

The results of numerical simulation for a soil representing one point in the catchment are not directly transferable to catchment scale. Yet, it is worth to note that the analysis of the rainfall-runoff events in the Jalovecký creek catchment (Kostka, 2009) showed that the lag time (time between rainfall maximum and peakflow) at the catchment scale varies between 1.4 and 3.4 hours.

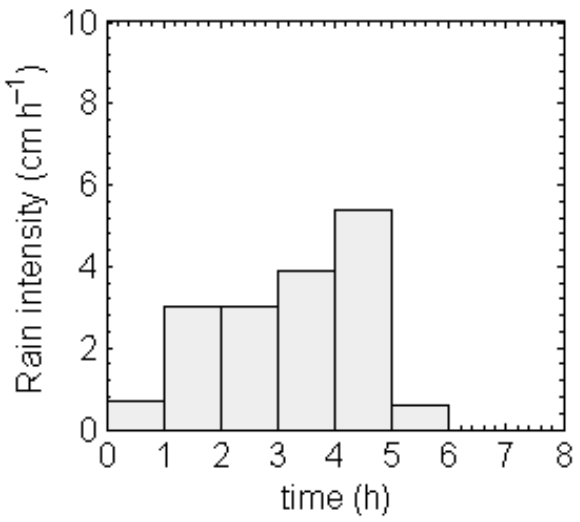

Fig. 7. Precipitation event measured on May 17, 2006 at meteorological station Červenec ( $1500 \mathrm{~m}$ a.s.l.) multiplied by the factor of 4 used as the upper boundary condition for the simulation.

The difference between cumulative outflow for soils of $R_{v}=$ $0 \mathrm{~cm}^{3} \mathrm{~cm}^{-3}$ and $R_{v}=0.5 \mathrm{~cm}^{3} \mathrm{~cm}^{-3}$ is highest for minimum initial SWC (Fig. 9b). The reason of this phenomenon is caused by relatively low retention capacity of the stony soil at $R_{v}=$ $0.5 \mathrm{~cm}^{3} \mathrm{~cm}^{-3}$ in comparison with the non-stony soil. Moreover, 

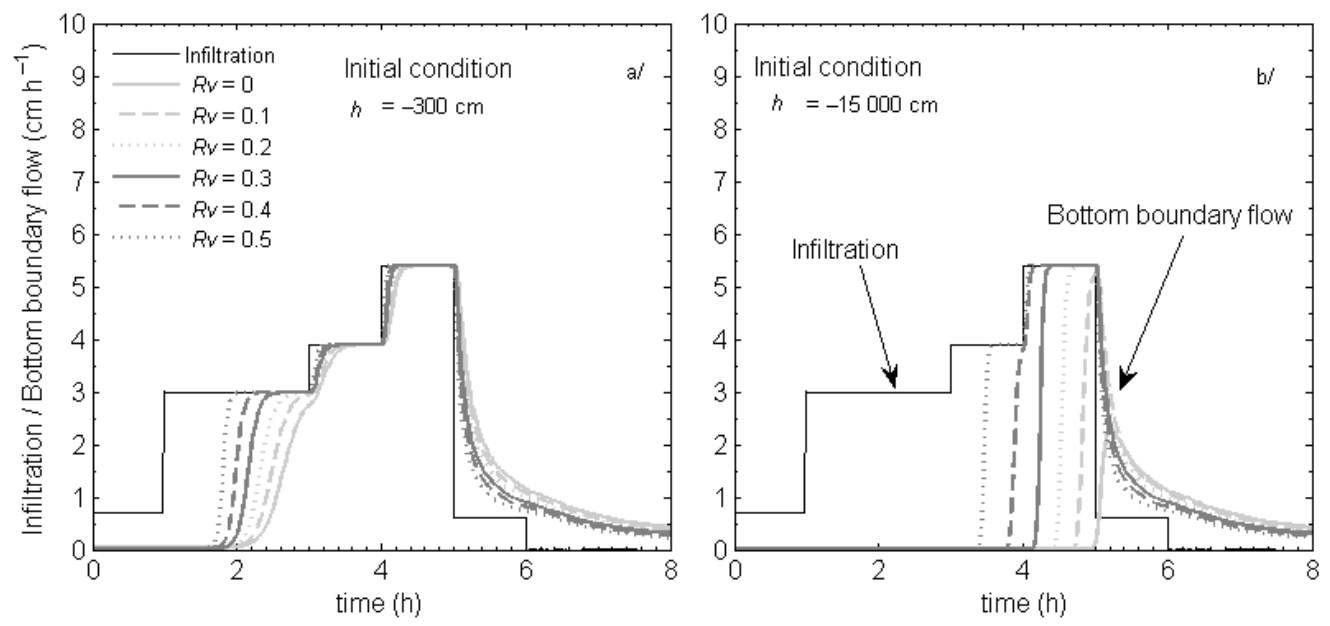

Fig. 8. Infiltration rate and bottom boundary flow rates to soil with different stoniness $R_{v}$ assuming an extreme precipitation event. a) initial soil water content corresponds to water potential $h=-300 \mathrm{~cm}$ (wet soil), b) initial soil water content corresponds to water potential $h=$ $-15000 \mathrm{~cm}$ (dry soil).
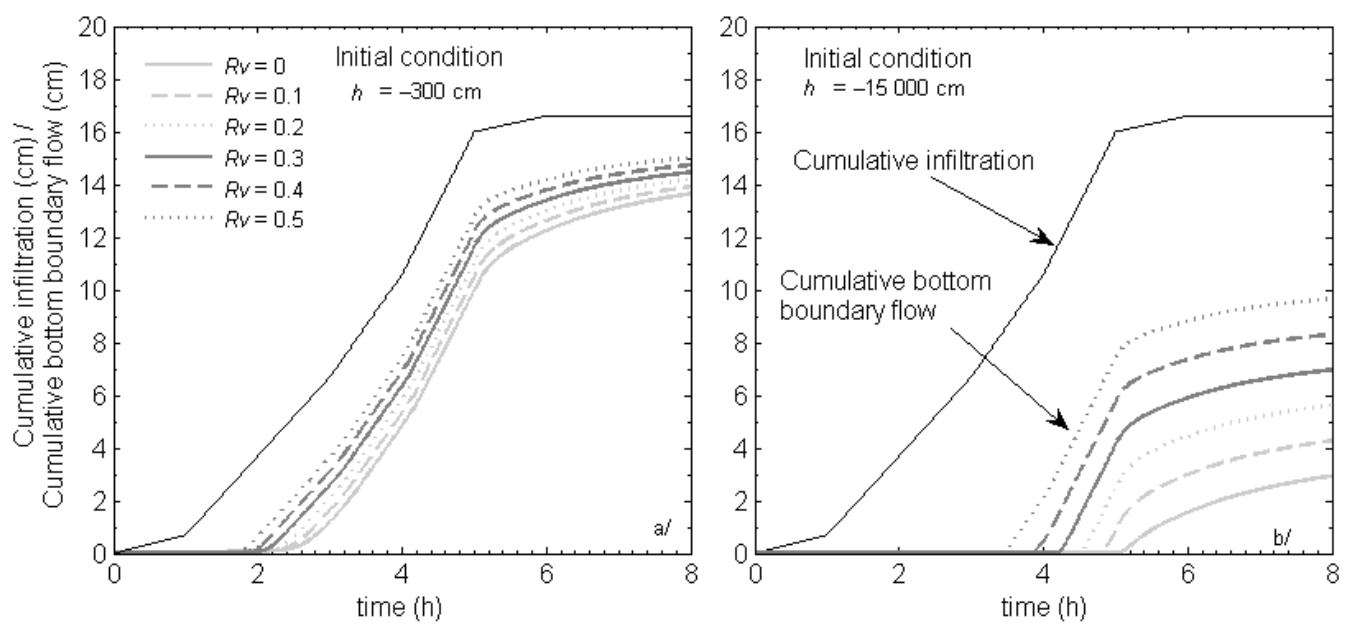

Fig. 9. Cumulative infiltration and cumulative bottom boundary flow for an extreme precipitation event. a) initial soil water content corresponds to water potential $h=-300 \mathrm{~cm}$ (wet soil), b) initial soil water content corresponds to water potential $h=-15000 \mathrm{~cm}$ (dry soil).

zero retention capacity of the rock fragments was assumed. In reality, the non-zero retention capacity of the rock fragments cannot change the overall response dramatically because of low retention capacity and low hydraulic conductivity of the rock fragments hampering water exchange between fine soil and rock fragments.

Cumulative outflows through the bottom boundaries of the stony soil profiles following the precipitation event shown in Fig. 7 up to 8 hours from the rain beginning are presented in Fig. 10a. Cumulative outflow from the soil profile depend on both initial SWC and stoniness. Wet soils with high stoniness showed higher cumulative outflow rates.

Fig. 10a shows that the bottom boundary outflow from the soil without rock fragments at the initial SWC corresponding to soil water potential $h=-300 \mathrm{~cm}$ equals to $82 \%$ of rainfall after 8 hours from the beginning of the rain event. In the soil with stoniness of $0.5 \mathrm{~cm}^{3} \mathrm{~cm}^{-3}$ the outflow represents $90 \%$ of rainfall. If the soil profile is drier at the beginning of the rainfall, the differences increase. In case of initial soil water potential $h=-15000 \mathrm{~cm}$ only $18 \%$ of the total rainfall flows out from the soil profile without rock fragments whereas in soil profile with stoniness of $0.5 \mathrm{~cm}^{3} \mathrm{~cm}^{-3}$ it is almost $58 \%$.
The response time, i.e. time from the onset of rainfall to the onset of outflow at the bottom of the soil profile (Fig. 10b) is inversely proportional to the initial soil water content and to the soil stoniness. Moreover, the smaller the initial soil water content, the higher the response time difference between stony soil with high stoniness $\left(R_{v}=0.5 \mathrm{~cm}^{3} \mathrm{~cm}^{-3}\right)$ and soil without rock fragments $\left(R_{v}=0 \mathrm{~cm}^{3} \mathrm{~cm}^{-3}\right)$. It is caused by already mentioned reduced retention capacity of stony soil and by consequently increased unsaturated hydraulic conductivity of stony soil profile. Such a behavior follows from the results shown in Fig. 10a which is described above.

\section{DISCUSSION}

Although there are many studies devoted to runoff processes on a forested hillslope e.g., Whipkey (1965), Mosley (1979), Tani (1997), Tromp-van Meerveld and McDonnell (2006), Hopp and McDonnell (2009), Kostka (2009), Hrnčír et al. (2010), Pavelková et al. (2012), and Dusek and Vogel (2014), rock fragments as a part of forest soils were not directly incorporated into the modeling. Cousin et al. (2003) used a reservoir model STICS to evaluate the effect of rock fragments on water 

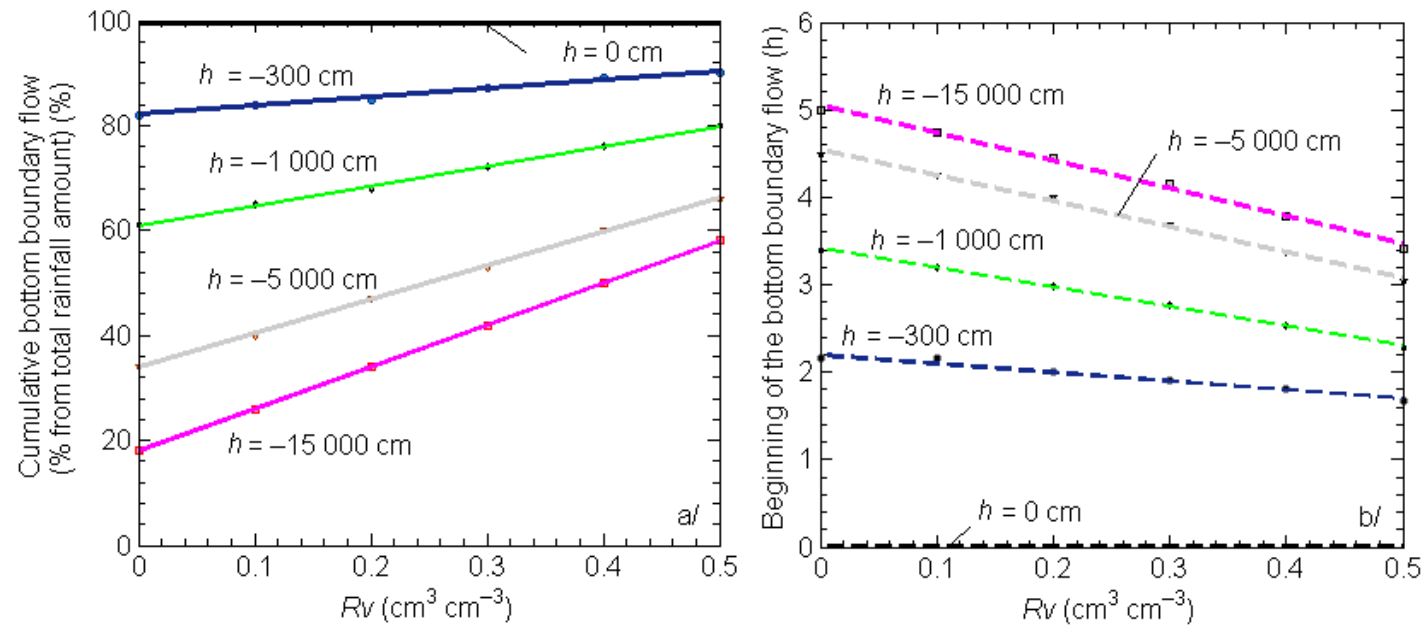

Fig. 10. a) Cumulative outflow from the soil profile bottom (in \% of the total rainfall) for 8 hours after the beginning of rainfall in the soils with different stoniness $\left(R_{v}\right)$ and with different initial soil water potentials. b) Response time, i.e. the time from the onset of rainfall and the onset of outflow at the bottom of the soil profile (in hours), in the soil profile with different stoniness $\left(R_{v}\right)$ and with different initial soil water potentials.

percolation to groundwater in calcareous stony soils during several seasons. They showed that cumulative percolation at base $(80$ or $50 \mathrm{~cm})$ of the stony soil profile with inert rock fragments they used was always higher in comparison to the stony soil with rock fragments of particular retention. The lowest percolation was found in the soil without rock fragments.

Presented results of water flow modeling are obtained for hypothetical stony soil profiles, where rock fragments of diameter $10 \mathrm{~cm}$ (parameter $a=1.1$ from the Eq. 1) are assumed to be uniformly distributed. However, real stony soil profiles are not homogeneous. The non-uniform distribution of the rock fragments in the soil profile could also affect the results of the water flow modeling. Simplification of the soil profile was necessary to demonstrate the potential influence of initial soil water content and stoniness on water flow through the soil profile.

Saturated hydraulic conductivity of a stony soil in natural conditions can vary due to stoniness (e.g., Ravina and Magier, 1984) or soil heterogeneity. The water movement is influenced not only by rock fragments, but also by organic horizon properties, soil structure and texture (both fine soil and rock fragments). Network of macropores or fissures can play important role as well. In the soils with notable clay content crack creation during soil shrinking can contribute to highly heterogeneous soil porous system (Allaire et al., 2009; Beven and German, 1982; Durner, 1994; Lin, 2010) and consequently to the occurrence of preferential flow (Dusek and Vogel, 2014; Šanda and Císlerová, 2009). Quick response of outflow to the rainfall in small mountainous catchments can be caused on the one hand by the fast preferential subsurface flow (Šanda and Císlerová, 2009; Tromp-van Meerveld and McDonnell, 2006), which is initialized at saturated or near saturated conditions, and on the other hand by the presence of rock fragments which will speed up the response even more.

\section{CONCLUSIONS}

This study presents characteristics of stony soils from mountainous catchment in the highest part of the Carpathian Mountains. The highest stoniness (up to 65\%) was found in Cambisols developed on the crystalline rocks. The lowest stoniness (up to $13 \%$ ) was measured in the Rendzic soil present on Mesozoic rocks.

The highest infiltration rate as well as the highest outflow from soil profile was calculated for ponded conditions and for homogeneous, non-stony soil under saturated conditions. Under ponding infiltration, the higher the stoniness the lower the infiltration rate and the bottom boundary outflow rate, because of decreasing saturated hydraulic conductivity with stoniness.

Infiltration of rainfall at a rate lower than infiltration capacity behaves in an opposite way. The higher the stoniness and/or initial soil water content, the faster the appearance of the bottom boundary outflow. Such a behavior stems from the fact that stones and high initial soil water content decrease available retention capacity and consequently increase unsaturated hydraulic conductivity. This may be a key factor explaining fast hydrological reaction of the Jalovecký creek catchment in which the stony soils dominate. Our results indicate that stoniness should be considered in the improved assessment of hydrological reaction of catchment with prevailing stony soils. Further research could involve spatially distributed data on stoniness and focus on timing of simulated outflow from the bottom of the soil profile and catchment runoff.

Acknowledgement. The help of Dr. Katarína Nováková of the fine soil particle size distribution and particle density measurement is gratefully acknowledged. We thank Dr. Tomáš Orfánus, Dr. Michal Danko and Ing. Jozef Hlavčo for their support in the field measurements.

The comments of the two anonymous reviewers and Dr. Jaromír Dušek that contributed to significant improvements of the manuscript are greatly acknowledged.

This publication contains results of project VEGA 2/0032/13, and Project ITMS 26240120004 supported by the Research \& Development Operational Program funded by the ERDF.

\section{REFERENCES}

Allaire, S. E., Roulier, S., Cessna, A., 2009. Quantifying preferential flow in soils: A review of different techniques. J. Hydrol., 378, 179-204. 
Beven, K., German, P., 1982. Macropores and water flow in soils. Water Resour. Res., 18, 5, 1311-1325.

Bičárová, S., Holko, L., 2013. Changes of characteristics of daily precipitation and runoff in the High Tatra Mountains, Slovakia over the last fifty years. Contributions to Geophysics and Geodesy, 43, 2, 157-177.

Bouwer, H., Rice, R.C., 1984. Hydraulic properties of stony vadose zones. Ground Water, 22, 6, 696-705.

Brakensiek, D.L., Rawls, W.J., Stephenson, G.R., 1986. Determining the saturated hydraulic conductivity of a soil containing rock fragments. Soil Sci. Soc. Am. J., 50, 834835.

Buchter, B., Hinz, C., Flühler, H., 1994. Sample size for determination of coarse fragment content in a stony soil. Geoderma, 63, 265-275.

Childs, S.W., Flint, A.L., 1990. Physical properties of forest soils containing rock fragments. In: Gessel, S.P., Lacate, D.S.,Weetman, G.F., Powers, R.F. (Eds.): Sustained productivity of forest soils, Proceedings of the $7^{\text {th }}$ North American forest soils conference. University of British Columbia, Faculty of Forestry Publication, Vancouver, Canada, pp. 95-121.

Coppola, A., Dragonetti, G., Comegna, A., Lamaddalena, N., Caushi, B., Haikal, M.A., Basile, A., 2013. Measuring and modeling water content in stony soils. Soil \& Tillage Research, 128, 9-22.

Cousin, I., Nicollaud, B., Coutadeur, C., 2003. Influence of rock fragments on the water retention sand and water percolation in a calcareous soil. Catena, 53, 97-114.

Dóša, M., Holko, L., Martincová, M., Danko, M., Kostka, Z., Gomboš, M., 2012. Determination of soil hydraulic conductivity in the mountain catchment by soil texture and field measurements. Acta Hydrologica Slovaca, 13, 2, 350 357. (In Slovak.)

Durner, W., 1994. Hydraulic conductivity estimation for soils with heterogeneous pore structure. Water Resour. Res., 30, 211-223.

Dusek, J., Vogel, T., 2014. Modeling subsurface hillslope runoff dominated by preferential flow: One- vs. twodimensional approximation. Vadose Zone J., 13, doi:10.2136/vzj2013.05.0082.

Fiés, J.C., De Louvigny, N., Chanzy, A., 2002. The role of stones in soil water retention. Eur. J. Soil. Sci., 53, 95-104.

Hewlett, J.D., Hibbert, A.R., 1967. Factors affecting the response of small watersheds to precipitation in humid areas. In: Proc. International Symposium on Forest Hydrology. Pergamon, Oxford, pp. 275-290.

Holko, L., Kostka, Z., Šanda, M., 2011. Assessment of frequency and areal extent of overland flow generation in a forested mountain catchment. Soil Water Res., 6, 1, 43-53.

Hopp, L., McDonnell, J.J., 2009. Connectivity at the hillslope scale: Identifying interactions between storm size, bedrock permeability, slope angle and soil depth. Journal of Hydrology, 376, 378-391.

Hraško, J., Bedrna, Z., 1988. Applied Soil Science. Priroda Publ. House, Bratislava, 474 p. (In Slovak.)

Hrnčíŕ, M., Šanda, M., Kulasová, A., Císlerová, M., 2010. Runoff formation in a small catchment at hillslope and catchment scales. Hydrol. Process., 24, 2248-2256.

Kostka, Z. 2009. Runoff response to rainfall event in the mountain catchment. (In Slovak with English abstract). Acta Hydrologica Slovaca, 10, 1, 130-139.

Lin, H., 2010. Linking principles of soil formation and flow regimes. J. Hydrol., 393, 3-19.
Lovelland, P.J., Whalley, W.R., 2001. Particle size analysis. In: Smith, K.A., Mullins, C.E. (Eds): Soil and Environmental Analysis Physical Method. Dekker Press, New York, USA.

Ma, D.H., Shao, M., 2008. Simulating infiltration into stony soils with a dual-porosity model. Eur. J. Soil Sci., 59, 950-959.

Ma, D. H., Shao, M. A., Zhang, J. B., Wang, Q., J., 2010. Validation of an analytical method for determining soil hydraulic properties of stony soils using experimental data. Geoderma, 159, 262-269.

Mosley, M. P., 1979. Streamflow generation in a forested watershed. Water Resour. Res., 15, 795-806.

Novák, V., Kňava, K., Šimůnek, J., 2011. Determining the influence of stones on hydraulic conductivity of saturated soils using numerical method. Geoderma, 161, 177-181.

Pavelková, H., Dohnal, M., Vogel, T., 2012. Hillslope runoff generation - comparing different modeling approaches. J. Hydrol. Hydromech., 60, 2, 73-86.

Peck, A.J., Watson, J.D., 1979. Hydraulic conductivity and flow in non-uniform soil. Workshop on soil physics and soil heterogeneity. CSIRO Division of Environmental Mechanics, Canberra, Australia.

Poesen, J., Lavee, H., 1994. Rock fragments in top soils: significance and processes. Catena, 23, 1-28.

Ravina, I., Magier, J., 1984. Hydraulic conductivity and water retention of clay soils containing coarse fragments. Soil Sci. Soc. Am. J., 48, 736-740.

Šály, R., 1978. Soil - Basic Component of Forest Production. Priroda Publ. House, Bratislava, 235 p. (In Slovak.)

Šanda, M., Císlerová, M., 2009. Transforming hydrographs in the hillslope subsurface. J. Hydrol. Hydromech., 57, 4, 264275.

Sauer, T.J., Logsdon, S.D., 2002. Hydraulic and physical properties of stony soils in a small watershed. Soil. Sci. Soc. Am. J., 66, 1947-1956.

Schaap, M.G., van Genuchten, M.Th., 2005. A modified Mualem-van Genuchten formulation for improved description of the hydraulic conductivity near saturation. Vadose Zone J., 5, 27-34.

Shi, Z., Wang, Y., Yu, P., Xu, L., Xiong, W., Guo, H., 2008. Effect of rock fragments on the percolation and evaporation of forest soil in Liupan Mountains, China. Acta Ecologica Sinica, 28, 12, 6090-6098.

Šimůnek, J., Šejna, M., 2007. HYDRUS (2D/3D), Software Package for Simulating Two- and Three-Dimensional Movement of Water, Heat, and Multiple Solutes in VariablySaturated Media. User Manual, Version 1.02. PC Progress, Prague, Czech Republic, 203 p.

Šimůnek, J., Šejna, M., Saito, H., Sakai, M., van Genuchten, M.Th., 2008. The HYDRUS-1D Software Package for Simulating the One-dimensional Movement of Water, Heat, and Multiple Solutes in Variably-Saturated Media. Version 4.0, Hydrus Series 3. Department of Environmental Sciences, University of California Riverside, Riverside, CA, USA, $281 \mathrm{p}$.

Tani, M., 1997. Runoff generation processes estimated from hydrological observations on a steep forested hillslope with a thin soil layer. J. Hydrol., 200, 84-109.

Tromp-van Meerveld, H.J., McDonnell, J.J., 2006. Threshold relations in subsurface stormflow: 1. A 147-storm analysis of the Panola hillslope. Water Resour. Res., 42, W02410, doi: 10.1029/2004WR003778.

van Genuchten, M.Th., 1980. A closed-form equation for predicting the hydraulic conductivity of unsaturated soils. Soil Sci.Soc.A.J., 44, 987-996. 
Verbist, K., Baetens, J., Cornelis, W.M., Gabriels, D., Torres, C., Soto, G., 2009. Hydraulic Conductivity as Influenced by Stoniness in Degraded Drylands of Chile. Soil Sci. Soc. Am. J., 73, 2, 471-484.

Vogel, T., van Genuchten, M.Th., Cislerová, M., 2001. Effect of the shape of the soil hydraulic functions near saturation on variably-saturated flow predictions. Advances in Water Res., 24, 133-144.
Whipkey, R.Z., 1965. Subsurface stormflow from forested slopes. Bull. Int. Assoc. Sci. Hydrol., 10, 2, 74-85.

Zhou, B., Shao, M., Shao, H., 2009. Effects of rock fragments on water movement and solute transport in a Loess Plateau soil. C.R. Geoscience, 341, 462-472.

Received 21 October 2013 Accepted 4 September 2014

Note: Colour version of Figures can be found in the web version of this article. 